SHORT REPORT

\title{
Sickle cell disease pain in London and the Caribbean
}

\author{
S Chakravorty, K Newell, J Ramchandani, K Qureshi, R Ibrahim, B Datta, P T Telfer
}

Arch Dis Child 2004;89:272-273. doi: 10.1136/adc.2002.020073

$P$ ain is a common symptom in children with sickle cell disease (SCD). Hospital admissions for treating pain are frequent in parts of the UK where SCD is prevalent. ${ }^{12}$ In Jamaica, pain is often managed at home or in a day care setting and analgesic use is probably less. ${ }^{3}$ The question is often asked whether sickle cell pain is less frequent and severe in Caribbean children or whether they have developed effective coping skills to reduce the impact of pain on daily activities. ${ }^{4}$ Observations of better school attendance and less frequent visits to hospital when in pain would be consistent with the latter.

There have been previous reports using pain diaries in SCD. ${ }^{56}$ In order to compare pain experiences, we designed a simple diary, and evaluated it in a simultaneous study of children in inner city London and on a Caribbean island.

\section{METHODS}

Inclusion criteria were a diagnosis of homozygous SCD, and age 5-15 (up to 24 in St Vincent). Exclusion criteria were chronic transfusion or hydroxyurea therapy. Sixty patients at the Royal London Hospital were selected randomly. In St Vincent all identifiable children were enrolled. Children (with parents help if aged 5-7) were asked to complete diary days over a four week period. The diary was designed in a simple, "child friendly" format with one A4 page per day. Parents were contacted at the end of two weeks to ensure compliance and address problems, and questioned at the end of the study. Hospital attendance data were checked with hospital records. Pain data were compared using nonparametric statistical tests. Ethical approval was granted by the East London and City Health Authority Research Ethics Committee and by the Kingstown Hospital Board of Governors.

\section{RESULTS}

Of the 60 children in London, 14 declined to participate, 17 were not contactable, six did not collect the diaries, and six did not return the diaries at the end of the study, leaving a total of 22 patients analysable. In St Vincent, 31 children were recruited. Three were found to have other diagnoses, four filled the diaries incorrectly, leaving a total of 24 analysable. The mean age at study entry was 10.5 (SD 3.41)

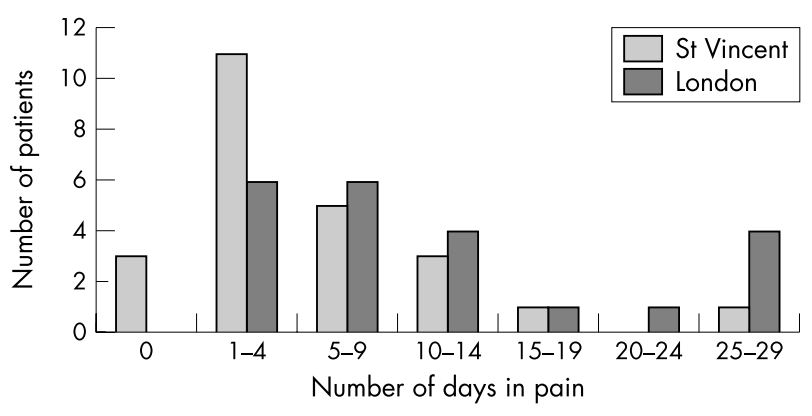

years in London and 12.3 (SD 5.39) in St Vincent. These differences were not statistically significant. There were $54 \%$ males in both groups.

A total of 1273 diary days were analysed. London children reported 243 (39\%) of 619 days with pain compared with 153 (23\%) of 654 days in St Vincent. London children were twice as likely to suffer a painful day (odds ratio $2.12,95 \%$ CI 1.65 to $2.72, \mathrm{p}<0.001$, fig 1 ). There was a significantly larger numbers of episodes of severe pain (maximal pain scores) among St Vincent patients compared to those in the London group (odds ratio $2.77,95 \%$ CI 1.68 to $4.55, \chi^{2} 18.6$, $\mathrm{p}<0.001)$.

St Vincent children suffered significantly more pain in the mornings. Pain occurred most frequently in the abdomen in both groups. There was a similar disruption of daily activities in the two groups (see table 1). Three London children visited casualty for pain relief during the study. All were admitted for intravenous morphine. In St Vincent four children visited casualty on six occasions. Two children were admitted to the ward for further treatment.

Painkillers were used on significantly more pain days by the London children: paracetamol $82 \%$ v 58\%, aspirin-like painkillers $14 \% \vee 1 \%$, outpatient opioids $64 \% \vee 0 \%$. Other types of pain management in London included "Vicks" and "rest"; in St Vincent, "penicillin", "warm milk", and "rest".

\section{DISCUSSION}

This study has shown that a simple diary can provide useful clinical information on sickle cell pain, and the majority of children are able to fill in the diary as instructed with parental help in some cases. Most of the pain was managed at home without hospital contact. London children experienced more days with pain, but severity was slightly greater in St Vincent.

The significantly greater use of analgesics drugs in London reflects the more aggressive therapeutic approach to pain in the UK and also the relative lack of resources in St Vincent. Contrary to our expectations, hospital attendances were equally frequent between the two sites, and children missed school equally frequently when in pain. It seems unlikely that children in St Vincent have developed more effective pain coping strategies, and pain appears to have a similarly disruptive effect on daily life in the two groups.

The study suggests that resources for managing sickle pain should be directed towards helping the child and the carers

Table 1 How pain affected daily activities (\% of pain days)

London (\%) St Vincent (\%)

\begin{tabular}{lrr}
\hline Absent from school/work & 38 & 41 \\
Unable to play & 27 & 18 \\
Stayed in bed & 12 & 21 \\
Visited casualty & 2 & 4 \\
Stayed in hospital & 7 & 4 \\
\hline
\end{tabular}

Figure 1 Frequency of pain days. 
as they cope with the pain at home. This would include appropriate use of oral analgesia, home visits by sickle nurse specialists, alternative therapies, and help in the development of psychological coping mechanisms.

\section{Authors' affiliations}

S Chakravorty, K Newell, J Ramchandani, K Qureshi, R Ibrahim,

B Datta, P T Telfer, Royal London Hospital, UK

Correspondence to: Dr P T Telfer, Department of Haematology, Royal London Hospital, Whitechapel Road, London El 1BB, UK; ptelfer@cytanet.com.cy

Accepted 6 July 2003

\section{REFERENCES}

1 Platt OS, Thorington BD, Brambilla DJ, et al. Pain in sickle cell disease. Rates and risk factors. N Engl J Med 1991;325:11-16.

2 Brozovic M, Davies S. Management of sickle cell disease. Postgrad Med J 1987;63:605-9.

3 Ware MA, Hambleton I, Ochaya I, et al. Day-care management of sickle cell painful crisis in Jamaica: a model applicable elsewhere? $\mathrm{Br} J$ Haematol 1999:104:93-6.

4 Thomas VJ, Hambleton I, Serjeant GR. Psychological distress and coping in sickle cell disease: comparison of British and Jamaican attitudes. Ethnicity and Health 2001;6:129-36.

5 Fuggle P, Shand PA, Gill $\sqcup$, et al. Pain, quality of life, and coping in sickle cell disease. Arch Dis Child 1996;75:199-203.

6 Shapiro BS, Dinges DF, Orne EC, et al. Home management of sickle cellrelated pain in children and adolescents: natural history and impact on school attendance. Pain 1995;61:139-44.

IMAGES IN PAEDIATRICS.

Wheezing with a whistle

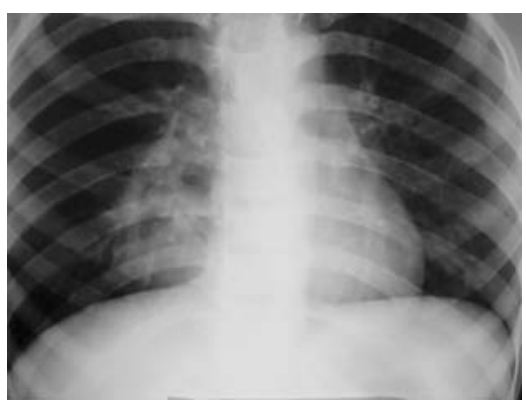

A 2 year old boy presented with history of sudden onset respiratory distress of three days duration. On examination he had right sided wheeze. Chest $x$ ray examination revealed a radio-opaque foreign body in the right main bronchus. An emergency bronchoscopy was done and the foreign body (a whistle used in toys) was removed, after which his wheeze subsided.

A B Sivam, M Nath Kanchi Kamakoti Child's Trust Hospital, Chennai, India; adhisivam1975@yahoo.co.uk

doi: 10.1136/adc.2003.037358 